\title{
Prenatal sonographic diagnosis of meconium peritonitis from duodenal atresia
}

\author{
Neeraja Chandrasekaran, ${ }^{1}$ Denise Benardete, ${ }^{2}$ Lisa Cariello, ${ }^{3}$ Diego Meraz ${ }^{4}$
}

${ }^{1}$ Cleveland Clinic Florida, Weston, Florida, USA

${ }^{2}$ Department of Obstetrics and Gynecology, Asociacion Medica del Centro Medico ABC AC,

Mexico DF, Mexico

${ }^{3}$ Santa Casa de Ribeirao Preto, Ribeirao Preto, SP, Brazil ${ }^{4}$ Department of Urogynecology, Medica Sur Lamos, Mexico City, Mexico

\section{Correspondence to}

Dr Neeraja Chandrasekaran, mdneeruthimma@gmail.com

Accepted 22 January 2017

\section{DESCRIPTION}

A primigravid woman aged 29 years presented for the first time to our antenatal clinic for routine check-up at 34 weeks of pregnancy. She denied any symptoms. Medical, surgical, social and family histories were reviewed and were unremarkable. Prior scans and prenatal workup from 7 to 15 , and 24 weeks were reviewed and were normal. Physical examination revealed a fundal height consistent with 34 weeks of pregnancy. Abdominal ultrasound scan detected $25.3 \mathrm{~mm}$ bowel dilation consistent with duodenal atresia, and ascites (figures 1 and 2). The fetus was diagnosed to have grade II meconium peritonitis secondary to duodenal atresia. Biophysical profile was performed on admission was 3. The decision for emergency caesarean section was made.

The infant was delivered and had an APGAR score of 3 . There were no apparent congenital anomalies. Cardiac abnormalities were ruled out by a 2D echocardiogram which was normal. An emergent laparotomy was performed and dilated necrotic bowel with a $0.5 \mathrm{~cm}$ perforation in the anterior aspect of the jejunum with spillage of bowel contents was observed. Resection of $5 \mathrm{~cm}$ of dilated and necrotic bowel, enterostomy placement and peritoneal drain placement was performed. The infant was transferred to the neonatal intensive care unit, extubated and weaned off haemodynamic support within 5 days postoperatively. Enteral feeds were started at 7 postoperative days. The remaining hospital course was uneventful, and the infant was discharged from the hospital at 20 days of life. The enterostomy was closed at the 6 th postoperative week. The infant was followed at 3 months and was found to be normal and asymptomatic.

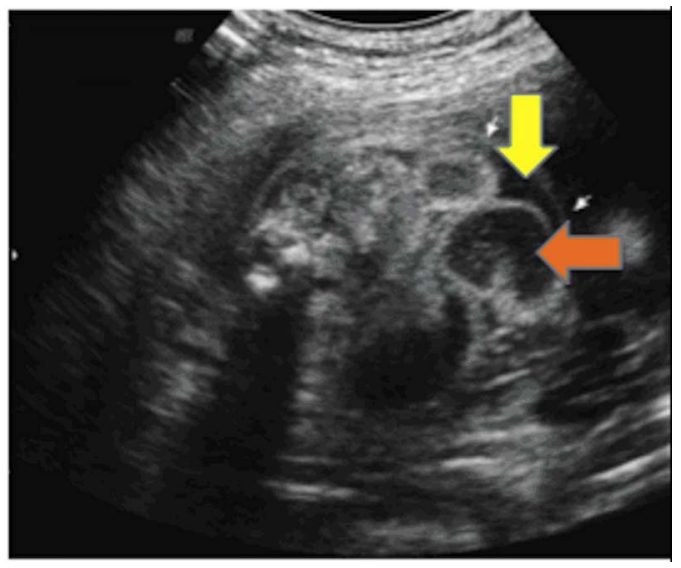

Figure 1 Double bubble sign signifying the bowel dilation of duodenal atresia (orange arrow). Ascites is also visible (yellow arrow).

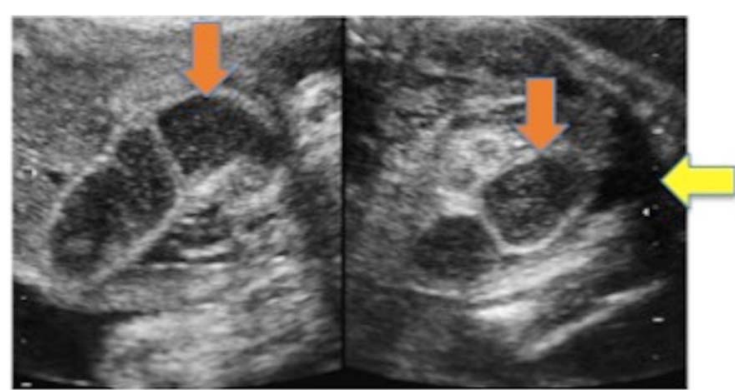

Figure 2 Bowel dilation (orange arrow) and ascites (yellow arrow) are present in this image. Hyperlucent intra-abdominal calcifications are also present around the bowel.

Meconium peritonitis is a sterile chemical inflammation of the peritoneum from intestinal perforation in utero. This occurs in 1:30 000 births with reported mortality of over $80 \% .^{1}$ Risk factors for meconium peritonitis include viral infections, gastrointestinal malformation causing bowel or biliary atresia, haemochromatosis and rarely cystic fibrosis. ${ }^{2}$ Zangheri et $a l^{3}$ created a classification system based on third trimester sonographic findings, which were related to perinatal outcome:

Grade 0: intra-abdominal calcifications (IAC) alone Grade I: IAC and one of the following: ascites, pseudocyst or bowel dilation

Grade II: IAC and two of the following ascites, pseudocyst or bowel dilation

Grade III: IAC+ascites+pseudocyst+bowel dilation

Saleh et $a l^{2}(\mathrm{~N}=14)$ found that fetuses with a grade $>1$ had the highest probability for requiring urgent neonatal surgery. Management of meconium peritonitis is based on prenatal diagnosis. The parents should be given prenatal counselling for

\section{Learning points}

- Meconium peritonitis is a rare condition with heterogeneous aetiologies, including viral infections, gastrointestinal malformation causing bowel or biliary atresia, haemochromatosis and rarely cystic fibrosis.

- Prenatal ultrasound scan findings of meconium peritonitis are predictive of neonatal outcomes.

- Physicians should always maintain a high index of suspicion when presented with unusual ultrasound scan findings and counsel the parents on the importance of continued care to prevent neonatal morbidity and mortality from meconium peritonitis. 


\section{Images in...}

understanding the importance of neonatal outcome. The patient should be transferred to a tertiary care centre with multidisciplinary care team, including an obstetrician, a neonatologist and a paediatric surgeon. ${ }^{2} 3$

Contributors NC was responsible for manuscript writing, editing and research. DB was responsible for manuscript editing and research. LC was responsible for manuscript editing and research. DM was responsible for overseeing the manuscript as a whole and providing guidance.

Competing interests None declared.

Patient consent Obtained.
Provenance and peer review Not commissioned; externally peer reviewed.

\section{REFERENCES}

1 Ali SW, ul Hassan M. Meconium peritonitis—a leading cause of neonatal peritonitis in Kashmir. Indian J Pediatr 1996;63:229-32.

2 Saleh N, Geipel A, Gembruch U, et al. Prenatal diagnosis and postnatal management of meconium peritonitis. J Perinat Med 2009;37:535-8.

3 Zangheri $G$, Andreani $M$, Ciriello $E$, et al. Fetal intra-abdominal calcifications from meconium peritonitis: sonographic predictors of postnatal surgery. Prenat Diagn 2007:27:960-3.

Copyright 2017 BMJ Publishing Group. All rights reserved. For permission to reuse any of this content visit http://group.bmj.com/group/rights-licensing/permissions.

BMJ Case Report Fellows may re-use this article for personal use and teaching without any further permission.

Become a Fellow of BMJ Case Reports today and you can:

- Submit as many cases as you like

- Enjoy fast sympathetic peer review and rapid publication of accepted articles

- Access all the published articles

- Re-use any of the published material for personal use and teaching without further permission

For information on Institutional Fellowships contact consortiasales@bmjgroup.com

Visit casereports.bmj.com for more articles like this and to become a Fellow 